\title{
Climate Change and its Consequences
}

\section{INTRODUCTION}

Climate change is one of the four "issues of global importance" I have identified in this work, along with demography, trade and technology. These, I believe, will influence human behavior and the behavior of nations in the years and decades to come. Climate change and what causes it are vast subjects that attracted a great deal of attention as the world prepared for the summit among nations in Paris at the end of 2015. This will not be the first attempt at developing a global consensus on addressing what is likely to become a major problem for humanity and the planet Earth if it is left unattended.

I begin with a discussion of what is meant by the term "climate change" and then very briefly explain what the accepted science tells us about the consequences of this phenomenon. I then identify the various measures that are being adopted or contemplated to address the problem. A special section on the use of coal is included in the chapter. This discussion illustrates the issues that surround both the economics and the politics of coal use in both the developed and the developing world. Another section links climate change with the rise of extremism in the world of Islam. Such a link may be bit of a stretch, but it helps to focus attention on some of the possible unpleasant consequences of global warming. Action needs to be taken not only to save the Earth but to prevent fissures among those who live on it. However, while there was virtual unanimity among the scientists studying the climate, there was still lack of consensus among policymakers about 
what needed to be done. As world leaders prepared to journey to Paris to participate in another "climate summit," some of those who needed to adopt domestic policies to prevent further heating of the Earth were not inclined to go as far as they needed to proceed.

The United States Secretary of State explained to the press shortly before leaving for Paris that a treaty would require approval by his country's Senate, where there were not enough votes for it to pass. Several important political figures in the United States remained skeptical about mankind's contribution to global warming. Among those who opposed government involvement in climate policy were several influential members of the Republican Party. On November 19, Senators James Inhofe and John Barrasso sent a letter to President Obama promising to block funding for any climate deal unless the Paris agreement, no matter what form it took, was sent to Congress for ratification.

\section{Contributing Factors to Climate Change and its Consequences}

Climate change has been a subject of inquiry for decades. In fact, as Peter Moore reminded his readers in an article in the New York Times, "the history of today's climate change debate may have begun on February 7, 1861. That day, an Irish physicist named John Tyndall, a professor of natural philosophy delivered the annual Bakerian Lecture to the Royal Society in London." He revealed that for two years he had been studying the heat-absorbing properties of gases. He noted that for the Earth's atmosphere to maintain its steady temperature, certain gases must be capable of trapping radiant heat. Gases such as oxygen, hydrogen and nitrogen retained very little heat. But others, particularly carbon dioxide, absorbed surprising amounts of radiation- "nearly 100 times as much as oxygen," he told his audience. ${ }^{1} \mathrm{He}$ described his findings as a breakthrough and indeed that is exactly what they were. His lecture led to a lively debate that has continued for a century and a half.

Scientists define statistical distribution of weather patterns when change lasts for an extended period of time. "Time" is defined in terms of decades, centuries, sometimes even millions of years. Within a given time frame climate change may be described as alterations of long-term weather conditions-more or fewer extreme weather occurrences. Initially changes were understood as having been caused by factors such as biotic processes, variations in solar radiation received by the planet Earth, plate 
tectonics and volcanic eruptions. Lately science and scientists have focused on human activities, such as the burning of fossil fuels that produce carbon dioxide or the production of methane gas by large herds of animals. Whereas nature's contribution to climate change cannot be controlled, human contributions can be reduced by adopting the right public policies. Since public policy choices in democracies must respond to the citizens' will and aspirations, it was inevitable that climate policy would become a highly contentious issue. This is the case when large economic interests are involved, as the mining of coal remains big business in some American states and several large emerging economies. There would be a more meaningful response to climate policies if citizens were better educated in the intricacies of the subject. Controlling climate change requires action on a number of different fronts.

According to one estimate the number of disasters caused by weather and climate have increased at a steady rate. When they are divided into three types-meteorological events such as storms; hydrological events such as floods, landslides and avalanches; and climatological events such as extreme temperatures, droughts and forest fires-their number has increased threefold, from about 300 in 1980 to 900 in 2014. In the 1980s and 1990s, most of the events were meteorological. By mid-2010s, both meteorological and hydrological events numbered about 400 each.

The human consequences of these events are not normally factored into the analyses of the adverse effects that can be attributed to climate change. A study published in June 2015 by the Lancet Commission on Health and Climate Change suggested that the World Health Organization and the Intergovernmental Panel on Climate Change had underestimated the future effects of global warming on health because they failed to take into account vulnerabilities caused by aging, migration and population growth. ${ }^{2}$

There have been, and will continue to be, significant differences in the regional consequences of climate change. South Asia has been one of the most affected areas. In 2015, Pakistan was ravaged by widespread floods caused by torrential rains. These could no longer be called "unprecedented"; this was the fifth time in seven years that heavy rains had flooded vast tracts of land in the country. The heatwave in India in May claimed almost 2,000 lives in the southern state of Andhra Pradesh, with most victims succumbing to heatstroke or dehydration. "Experts suggested India's heatwave foreshadowed worse to come, with South Asia likely to suffer significant increase in potentially deadly combination of heat and humidity as a result of global warming." This warning turned out to be right when 
a heatwave in Karachi, Pakistan's largest city with a population of more than 20 million, resulted in more than a thousand deaths. "The surge in temperatures to $46 \mathrm{C}$ - the highest in recent memory-appears to confirm warnings that climate change is upsetting weather patterns across South Asia, experts say." 3

In November 2012 the World Bank issued a report that painted a dismal picture of the situation in some parts of the world as a result of global warming. According to its findings, temperatures are already 0.8 degrees Celsius higher than they were in the 1800s. The Bank's report said that there was, in fact, a "robust" increase in the number of droughts, storms and floods and landslides over the past 50 years. "...the number of disasters counted nearly doubled between the mid-1990s and 2010-2014." Those who advocate political action set the target at an increase in 2 degrees as the maximum the globe could tolerate. Even at that level, yields of soya beans in Brazil could decline by as much as $75 \%$ and those of wheat in South Asia by $50 \%$. Agriculture is not the only sector that would be adversely affected. Global warming has begun to change the patterns of disease in the world. For instance, the 2012 outbreak of the West Nile virus in Texas was attributed to climate change. "With warmer weather, mosquitoes fly more and bite more. And warmth amplifies the infectivity and replication of the virus," said Robert Haley, director of epidemiology at the University of Texas Southwestern Medical Center and the coauthor of a major study on the 2012 outbreak. The arrival of zika carrying virus in the United States' south was attributed by experts to global warming. "If everything else remains the same you could predict that a warmer climate makes things worse. ${ }^{5}$

Global warming could also have consequences that are not directly related to climate change. For instance, some political analysts believe that climate change is already leading to political action in the world's most crowded regions. They suggest that droughts in the Middle East and North Africa may be one of the reasons behind the Arab Spring of 2011, as the economically deprived were responding to the rise in grain prices. Prices rose because of droughts in the region. Some analysts also consider climate change to be a contributing factor in the rise of extremist Islam in parts of the Middle East and South Asia.

\section{Three Men in the Climate Boat}

Three men, in three very different ways, sought to overcome the resistance to the use of the state to tackle the problem of global warming. The right public policy choices will help to stop the planet Earth moving towards a 
disaster of an extent and scope that has begun to be understood as climate science has made many advances. President Barack Obama, a pragmatic liberal and a strong believer in an activist state in matters where firm action needs to be taken, was convinced that global warming had to be controlled. In his first term he tried to push a "cap-and-trade" program through Congress. But the measure died in the Senate, in part because lawmakers from both political parties feared that a serious climate policy could threaten economic competition with China. Politics was not on the American president's side during the entire length of his stay in the White House.

President Obama spent more time on climate issues during his presidency than on any other international issue. During his late November 2015 meeting in the White House with French President Francois Hollande, he veered from his focus on the terrorist attacks in Paris to talk about the large international gathering beginning in the French capital on November 30. "What a powerful rebuke to the terrorists it will be when the world stands as one and shows that we will not be deterred from building a better future for our children," he said while speaking to the press. "The segue brought mockery, even castigation, from the political right, but it was a reminder of the importance Mr. Obama places on climate change in shaping his legacy," wrote Coral Davenport in an assessment for the New York Times. "During his 2012 reelection campaign, he barely mentioned global warming, but the issue has become a hallmark of his second term."

Xi Jinping, the Chinese president, did not have to convince his people that a strong state was needed to bring about change in most matters. What brought him to the point where his country became the world leader in using public policy in the area of climate change was the dense fog that enveloped Beijing, his capital, most of the time. Draconian measures had to be adopted by the government to clean the capital's air for such major crowd-attracting events as the 2008 Beijing Olympics and the September 3,2015 celebration of the defeat of Japan at the end of the Second World War. Air pollution had triggered widespread respiratory illnesses, as well as hundreds of thousands of premature deaths. The increase in life expectancy that was the norm in most societies, developed and developing, was arrested in China because of the damage done to health by increasing air pollution. Over time, the Chinese authorities had become aware of the economic cost of the persistent deterioration in air quality. They were prepared to take action.

For the United States, where a significant number of people and politicians still believed that climate science was a hoax perpetrated by those who wished to give the state power over private enterprise, the voice 
that was clearly heard was that of Pope Francis, the third man on the climate boat. We won't always remember all of the details of his several pronouncements-but we can remember the Pope saying before the UN General Assembly that "any harm done to the environment is harm done to humanity." The call for action by way of public policy received a boost by the encyclical issued by the pope on June 17,2015. Titled Laudato Si, the Pope echoed the virtually unanimous findings of mainstream scientists. He fixed the blame squarely on humans and their burning of fossil fuels while warning of on "unprecedented destruction of ecosystems with serious consequence for all us." The hardest hit-here again the Pope followed mainstream thinking-would be the poorest citizens of the poorest countries, those least able to adapt to the rising seas and devastating droughts and floods that are likely to occur even in this century without urgent remedial action.

The pontiff continued with his campaign during a visit to the United States in late September 2015. Climate was one of the many themes he touched upon in his public addresses, including those to a joint sitting of Congress and the United Nations General Assembly. His words in Washington on the environment were relatively conciliatory. "He sought 'dialogue' - a word the pontiff used 12 times. He did not even explicitly mention the words 'climate change' though he did call on Congress to help "avert the most serious effects of the environmental deterioration caused by human activity." ${ }^{7}$ However, in his United Nations speech he was much more explicit, building on the Laudato Si encyclical. "The ecological crisis, and the large-scale destruction of biodiversity, can threaten the very existence of the human species. The baneful consequences of an irresponsible mismanagement of the global economy, guided only by ambition for wealth and power, must serve as a summons to forthright reflection on man and his actions," he told his international audience. He also spoke deliberately in the United Nations' language of rights but pushed to broaden the very concept. "First, it must be stated that a true 'right of the environment' does exist, for two reasons. First, because we human beings are part of the environment. Second, any harm done to the environment, therefore, is harm done to humanity."

\section{The Need for International Action}

There was some irony in the fact that the biggest push to use the market to curb atmospheric pollution came from a country where the state held the reins of economic power. The cap-and-trade approach became the 
cornerstone of China's approach in its effort to curb the use of coal. This approach, conceived by American economists, is for governments to place a cap on the amount of carbon pollution that may be emitted annually. The rest is left to private enterprise, as companies can then buy and sell permits to pollute. Western economists have long backed the idea as a market-driven way to push industry to cleaner forms of energy, by making polluting energy more expensive. But the initiative taken by Beijing, although it did not have the full support of the captains of industry, was far-reaching. According to a story in the New York Times, "China's economy depends heavily on cheap coal-fired electricity, and the country has a history of balking at outside reviews of its industries. China has also been plagued by major corruption cases, especially among coal companies." 8 As with most other major policy moves, Beijing tried the cap-and-trade approach in a pilot project in seven Chinese cities before announcing its application nationwide.

Climate change and the damage it can do to life on Earth began to receive serious attention as the world prepared for the next global summit on the subject, the meeting held in Paris in November 2015. This was not the first attempt at the development of international consensus on public policy choices that needed to be made by governments around the globe. The first serious attempt was made in 1997 and resulted in the adoption of the "Kyoto Protocol" — so-called because it was written at an international meeting held in the Japanese city-that committed governments to reduce the emission of greenhouse gases. It was based on two premisesthat global warming was a scientifically established phenomenon and that it was caused primarily by human activity. The Kyoto meeting entrusted the United Nations Framework on Climate Change (UNFCC) to implement the provisions of the protocol. It entered into force on February 16, 2005 with 192 countries agreeing to follow it. According to Article 2 of the protocol it was the responsibility of the UNFCC to reduce greenhouse gas concentrations in the atmosphere to a "level that would prevent dangerous anthropogenic interference with the climate system."

The protocol's first commitment period started in 2008 and ended in 2012. A second commitment period was agreed to in 2012. Known as the Doha Amendment, it was endorsed by 37 countries and included binding targets. However, the United States failed to ratify and Canada withdrew from the protocol. By that time a different administration than the one that had negotiated Kyoto was in office in Washington. There was some irony in the fact that while then Vice President Al Gore was the leading 
player at Kyoto, it was the United States that essentially killed the international agreement. After leaving office in 2012, Gore went on to become a prominent exponent of climate control-his efforts in the area had won him the Nobel Peace Prize in 2007. Negotiations were held in Lima, Peru in December 2014 to agree on a post-Kyoto legal framework that would commit all major carbon dioxide emitters-China, India and the United States-to make formal pledges. But these countries held out for several years. However, in November 2014 China and the United States agreed to join the effort. India took much longer to commit and even when it did, its plan was considerably less ambitious than China's.

Some experts, drawing a lesson from the success of the Montreal Protocol, suggested that large corporations should be the focus of attention rather than almost 200 governments trying to reach a consensus on what needs to be done to prevent disaster. In September 1987, representatives of 24 countries met in Montreal and "accomplished a rare feat in international politics: a successful environmental accord," wrote Jerry Patchell and Roger Hayter in an article for Foreign Affairs. " The then UN Secretary General Kofi Annan called the protocol "perhaps the single most successful international agreement to date." The Montreal Protocol on Substances that Deplete the Ozone Layer set the ambitious goal of phasing out chlorofluorocarbons (CFCs) and other dangerous chemicals. It worked: by 1996, less than two decades after the agreement was signed, developed countries had stopped their production of CFCs, and by 2006 , the 191 nations that had ratified the protocol had eliminated $95 \%$ of ozone-depleting emissions. This happened as the protocol put economic pressure on a small number of companies that produced or consumed most of the CFCs. The firms responded to the pressure by developing alternative methods to replace the dangerous chemicals. Science, technology and economics came together to solve the problem.

Unfortunately, the success achieved by the Montreal Protocol eluded the world's greatest collective challenge: stopping global warming. One reason was the process chosen. The UNFCC, made responsible for obtaining a consensus, put in place a negotiating process that did not give attention to bringing about change where it was needed the most: economic considerations that would alter the behavior of the corporate world. The UNFCC "failed because it does not provide powerful enough directives for companies to develop and use technologies that could radically reduce their greenhouse gas emissions. Unlike the Montreal Protocol, the 
UNFCC does not focus on specific internationally traded products that generate harmful emissions." 10

\section{Coal as a Source of Producing Energy}

There are actually two main types of coal: "thermal coal," which is mostly used for heating and power generation, and "metallurgical coal," which is mostly used for steel production. Thermal coal is more abundant, has a lower carbon content and is higher in moisture than metallurgical coal.

It was the Industrial Revolution (United Kingdom) in the 1800s that played a major role in bringing about the extensive use of coal in its various forms. Not only was it the most abundant fuel in the fossil family, it could be used in its natural form and could also be conveniently extracted from near the Earth's surface. Coke replaced charcoal as the primary fuel for iron blast furnaces to make steel, and with steamships and steampowered railroads becoming the chief mode of transportation, coal was also used to fuel the boilers. Soon, the use of coal became synonymous with industrialization and coal mines began to develop rapidly throughout the world. However, its use in generating electricity came much later, during the 1880s. Today, $75 \%$ of the coal mined in the world is used for generating power.

The use of coal grew steadily over the years, more rapidly than the increase in the use of oil or natural gas. In fact, growth in coal consumption this century has almost equaled growth in oil, gas, nuclear and renewables combined. ${ }^{11}$ This increase in coal consumption throughout the world in recent decades has primarily been due to greater need for electricity generation in China, India and other non-Organization for Economic Cooperation and Development (OECD) countries that have seen total power generation double since 2000. According to the International Energy Agency (IEA), coal demand will reach 9 billion tons by 2019. ${ }^{12}$ The primary reason behind this is supply and demand. Coal is the cheapest source of energy; cheaper than oil, natural gas, nuclear or hydro energy. With oil reserves limited and concentrated in the Middle East-a region in turmoil in the 2000s - its supply as well as its price were subject to uncertainty. Coal reserves, on the other hand, are spread throughout the world in large amounts and can be easily extracted with simpler technology. Also, given that it is a solid, it is easier to transport and has a higher energy density than oil.

As Tables 12.1 and 12.2 show, the three largest producers of coal are also the world's three largest consumers. Since coal is the largest contributor to 
Table 12.1 Main coal producing countries in 2013

\begin{tabular}{llcc}
\hline Rank & Country & Production (in million tons) & Share of total (in \%) \\
\hline 1 & China & 3,561 & 45.5 \\
2 & United States & 904 & 11.6 \\
3 & India & 613 & 7.8 \\
4 & Indonesia & 489 & 6.3 \\
5 & Australia & 359 & 5.9 \\
6 & Russia & 347 & 4.4 \\
\hline
\end{tabular}

Source: International Energy Agency, 2013

Table 12.2 Main coal consuming countries in 2012

\begin{tabular}{llcl}
\hline Rank & Country & Consumption (in million tons) & Share of total (in \%) \\
\hline 1 & China & 3,881 & 50.7 \\
2 & United States & 805 & 12 \\
3 & India & 791 & 8.5 \\
4 & Japan & 316 & 3.4 \\
5 & Russia & 233 & 2.4 \\
6 & South Africa & 187 & 2.3 \\
\hline
\end{tabular}

Source: International Energy Agency, 2013

carbon emissions in the Earth's atmosphere, the largest consumers need to play a major role in curbing the use of this substance. Given that there currently appears to be no prospect of meeting the growing global electricity demand without coal, governments around the world must implement policies that that respond more aggressively to the growing use of coal. Monitoring of efficiency of power plants and targeting those that perform poorly would be an important step in that direction.

In July 2015, the OECD released figures that caused alarm in the international community. Coal-fired power plants will release 500 billion tons of carbon dioxide by 2050; this was equivalent to half of the global carbon budget that would ensure that the increase in the Earth's temperature remains within the limit of 2 degrees Celsius (and no dangerous climate change occurs). Such findings, ahead of the UNFCC conference in Paris in 2015, put huge pressure on the three major coal-consuming nations to come out with coal control policies. While the United States and China have pledged to implement coal control measures in their countries, India's stand on the fuel for power generation was not considered satisfactory. 
The geographical distribution of coal production and consumption is likely to change significantly as the two largest producers and consumers-China and the United States-move to reduce the use of the fuel. However, South Asia, with India in the lead, is set to emerge as the largest user and thus the largest emitter of carbon.

India's coal consumption was the highest in the world in 2014, representing $11.1 \%$ of the total, and several new plants have been approved and are under construction. It has invested heavily in coal-fired power generation and its installed capacities are relatively new with long operational life, unlike those of other OECD countries. The IEA policy projection for India, in the form of its 2050 Scenario, envisions coal-fired power to decline to $18 \%$ by 2040 . This requires advances in nuclear, hydro, solar and bio energy capacities as well as the premature closure of many coalfired plants. However, this seems highly optimistic and would require a significant shift in government policy.

India saw a similar trend in coal use as the rest of the world. Coal mining in India, which started in the late 1700s under British rule, initially was limited due to lack of demand. However, after the introduction of steam locomotives, it rose exponentially to an average annual production of 1 million tons. After independence, the Government of India nationalized coal industry in the 1970s and Coal India Limited became the largest coal producing company in the world. Today, India is one of the world's top coal producers and consumers; almost three-quarters of electricity generated in India in 2012 came from coal-fired power plants, according to the World Bank. India has the fifth-largest coal reserves in the world (after the United States, Russia, China and Australia) estimated at 60 billion tons. The actual reserves could be much more, as coal resources have usually proven to be four to five times greater than estimated. ${ }^{13}$ According to the IEA in 2012, China (3,549 million tons) was the largest coalproducing country in the world, followed by the United States (935 million tons) and India (595 million tons). The order of consumption also follows the same pattern.

However, according to IEA there is still a huge gap in India's coal consumption and production in the past decade, which has led to imports of thermal coal by India growing from 12 million tons in 2004 to 142 million tons in 2013.

In 2012, coal consumption in South Asia was about 685 million tons, of which 98 \% was in India. Despite having sufficient reserves, a lack of capacity and infrastructure have meant that they have not been 
fully exploited. According to the 2012 Pakistan Energy Yearbook, $31 \%$ of Pakistan's energy was generated by oil, $50 \%$ by gas and only $6.6 \%$ by coal. Although Pakistan has large coal reserves of about 185 billion tons, the seventh largest in the world, it uses very little of this particular fuel to produce electricity. But that is set to change. The nation was coping with energy shortages of up to 6,000 MWs with the industrial sector the hardest hit. It is finally turning to coal for solving its energy crisis and seeking foreign investment despite public dissent on its environmental consequences. China has committed to invest around \$2 billion in coal-fired power projects in Pakistan. Several UK, UAE and Czech-based companies are also interested in making similar investments in the country.

Bangladesh and Sri Lanka are also trying to head in the same direction but meeting with much political resistance. Currently, $75 \%$ of Bangladesh's power generation comes from natural gas, and the country has only one coal mine which is also in development stage. However, several investors have pulled out, most recently Norway, from its first major coal-fired power project near Sundarbans, citing environmental concerns. Sri Lanka has only two coal power stations but due to several accidents in the Norochcholai power station in the past, no further coal power stations have been commissioned. Currently, over half of the country's power generation comes from imported oil and natural gas. Table 12.3 shows the percentage of coal consumption for generating power in different countries of South Asia. While India has always maintained a high usage of coal for meeting its power demands, the same remains untapped in other South Asian countries.

According to a report issued by the IEA in 2015, coal-fired plants provide over $42 \%$ of global electricity supply. ${ }^{14}$ At the same time, these plants account for over $28 \%$ of global carbon dioxide emissions. Energy

Table 12.3 Use of coal for power generation (in \%)

\begin{tabular}{llllc}
\hline Year & India & Pakistan & Bangladesh & Sri Lanka \\
\hline 1980 & 51 & 0.2 & 0.0 & 0.0 \\
1990 & 65.5 & 0.1 & 0.0 & 0.0 \\
2000 & 68.5 & 0.4 & 0.0 & 0.0 \\
2005 & 66.9 & 0.1 & 0.6 & 0.0 \\
2011 & 66.8 & 0.1 & 1.8 & 8.9 \\
2012 & 71.1 & 0.1 & 1.8 & 11.8 \\
\hline
\end{tabular}


efficiency of coal plants, therefore, is an important subject. It is, as discussed below, central to the policies and programs announced by China and the United States in preparation for the climate summit in Paris at the end of 2015. In their summit held at Gleneagles in July 2005, the G8 group of rich industrial countries requested a review and assessment of the energy efficiency of coal-fired plants. This was done so that policymakers could reflect on what steps were needed to improve the overall efficiency of power generation from coal. The review emphasized that the return from improving efficiency was large; some estimates suggest that 1.7 GtCO2 (gigatons of Carbon Dioxide) could be saved annually. However, securing that end would require a major realignment of national energy and environmental policies, a realignment that may be less politically acceptable than allowing old, inefficient coal-fired plants to continue running in the expectation that they will eventually fade away.

While coal was the main culprit in warming the Earth, there were other important contributors. The Food and Agriculture Organization estimates that the global meat industry belches about $14.5 \%$ of the world's greenhouse gas emissions, more than all the world's cars, trucks, ships and planes combined. In a report published in 2014, Chatham House called the livestock industry the forgotten sector of climate change. "The think-tank believes that a two-degree rise in global temperature over the pre-industrial average, above which the effects of climate change become hard to predict, cannot be averted without a change in global meat and dairy consumption." 15 There was some irony in the fact that on the eve of the Paris climate talks, China's official news agency promised to make the country a major player in agricultural biotechnology. A Chinese company was teaming up with one from South Korea to clone one million cattle a year to feed public demand for high-quality beef.

\section{Individual Country Actions and the Politics of Burning Coal for Generating Electric Power}

On August 2, 2015 President Barack Obama announced his "clean power plan," which required the country's power plants to cut their carbon dioxide emissions to $32 \%$ below the 2005 level by 2030 . Power plants are the largest source of such pollution in the country, accounting for more than a third of the country's total carbon dioxide emissions. The Obama plan, coming a few months before the Paris climate summit, gave a strong indication to the international community that the United States-or at 
least the country's executive branch-was finally ready to make a move in this critical area. There was no doubt that the politically well connected coal-based energy sector would have to make major adjustments. A study by the United States Energy Information Administration estimated that at least 90 gigawatts of coal-fired generating capacity will be retired and that just half of that loss will be caused by the president's plan. But as a report in the New York Times put it, "the truth is that most of the coal plants at risk should have been shuttered years ago. Traditionally, the economically useful life of a coal plant was thought to be about 30 years. As of 2014, coal-fired plants in the United States had been operating for an average of 42 years, and many plants had been in service for far longer. Some date all the way back to the 1950s, meaning they have already been running for twice their expected lives." 16

President Obama based his executive order on the Nixon-era Clean Air Act, passed in 1970 with almost unanimous support with the goal and ambition of eliminating essentially all air pollution. But this law contained a major flaw: existing plants were exempt from its provisions. President Obama's plan sought to close this loophole and would be most definitely challenged in the courts. It ran into political opposition the moment it was made public. Mitch McConnell, Republican senator from Kentucky, a state in the heart of the country's coal belt, and the Senate majority leader, denounced the plan as the "latest and most damaging attack in the president's 'war on coal." He committed himself to defeating it in Congress and invited the coal industry and the citizens of the coal state to join him in the effort. The senator followed up on this threat with more threats. In an article published by the Washington Post a day before the Paris conference began, the senator advised the Paris conferees not to heed the entreaties of a president who was nearing the last year of his presidency and had little domestic support for some of the actions he was taking by using executive orders. "It would be irresponsible for an outgoing president to purport to sign the American people up to international commitments based on a domestic energy plan that is likely illegal, that half of the states have sued to halt, that Congress has voted to reject and that his successor could do away with in a few months' time," he wrote. ${ }^{17}$

While the 1970 Clean Air Act left the cities in the United States without much visible air pollution, thus reducing pressure from citizens to further reduce carbon dioxide emissions, this was not the case in China. Most of the inhabitants of large cities suffered from severe atmospheric pollution. Dense fog in Beijing, the country's capital, became the norm. 
The government had to take extraordinary measures to clean the air for special events such as the Beijing Olympics, when factories were closed and most automobiles were removed for the duration of the games from the city's clogged streets. China is the world's biggest carbon emitting nation, accounting for nearly $30 \%$ of total greenhouse gas emissions.

The situation in China was different from that in the United States. The people demanded action and that came in the form of a joint statement by President Xi Jinping and Barack Obama when the two met on the sidelines of the annual Asia-Pacific Economic Cooperation summit hosted by China in November 2014. The highlight was the announcement by Xi and Obama of an ambitious Sino-US plan to cut carbon dioxide emissions. Groundwork had been done for months by senior officials of the two governments to prepare the joint statement. For reasons of domestic politics, China gave up its demand that it, along with other developing countries, should not be expected to adopt draconian measures when much of the responsibility for the accumulation of carbon dioxide in the upper layers of the atmosphere lay with the unconstrained use of fossil fuels by the developed world when it industrialized. The government pledged that by 2020 it will reduce by $40-45 \%$ the amount of carbon produced for every unit of gross domestic product and will reach a peak emission level by 2030 .

India came late in terms of making its commitment. On October 1 , a couple of months before the Paris meeting, the government published a 38-page plan that committed India to reduce the intensity of its fossil fuel emissions by 33-35\% from 2005 levels by 2020. The aim was to produce $40 \%$ of its electricity from non-fossil fuel sources such as wind, solar power, hydropower and nuclear energy. As shown in Tables 12.1 and 12.2, India was the third-largest producer of coal and also the third-largest consumer of the fuel. The announcement from New Delhi was received with some relief by the groups around the world that were pressing the main users of the fuel to cut down on their consumption levels. However, under the plan India did not commit to an absolute reduction in carbon levels, unlike other major polluting economies including those of the United States, China, the European Union and Brazil. India's emissions would continue to rise but at a slower pace compared to business as usual. There were two important changes in the traditional Indian position: it did not seek compensation from the advanced countries whose industrialization over a period of more than a century had led to the accumulation of carbon in the atmosphere in the first place, and it seemed prepared to accept binding targets as part of an international agreement. There were 
reports that India and the United States were working on the transfer of low-carbon technology from the United States to India. ${ }^{18}$

The Indian government committed itself to making sincere efforts in developing renewable energy technologies not only to reduce dependency on coal imports but to improve the air quality that was rapidly worsening. But curbing the use of coal could have a limiting impact on the country's growth. According to a 2012 report issued by the Indian Chamber of Commerce, coal contributed to more than $1.5 \%$ of the country's GDP and was a source of employment for millions of people. Besides power generation, cement and steel sectors were major coal users in India. Researchers found a direct relationship between India's coal consumption and its GDP. India's coal consumption has increased over the years and there is still a huge gap between demand and supply, which only implies that India will be using more coal in the future.

\section{The Paris Climate Summit}

The world nations met in Paris for two weeks beginning on November 30, 2015. The meeting was held 17 days after a terrorist attack that left 130 people dead. The UNFCC, the agency responsible for implementing international action concerning climate change, adopted a different approach in organizing the Paris deliberations. Nations attending the conference were required to submit their plans. This requirement was met by 186 nations. The story of how the Paris accord, announced on December 12, was reached started long before the representatives of nearly 200 countries traveled to Paris. The approach the French hosts took was different from the one adopted by the Danes in conducting the failed climate meeting in Copenhagen in 2009. The hosts of that event had set a stern tone, with concrete barricades, concertina wire and steel cages to house protesters who stepped out of line. In spite of the terrorist attack of November 13, the French adopted a more relaxed and friendly approach.

"After Copenhagen, many world leaders believed that the United Nations process would no longer work for tackling climate change," said Ban Ki-moon, the United Nations Secretary-General. What changed from Copenhagen to Paris? Three things: a fundamental change in the geopolitics of climate change; a shift in the perception of global warming from a distant warning to an immediate threat; and the French government's approach to the meeting. The most important change in geo-politics was made by Washington and Beijing. According to one assessment, 
"Americans had historically demanded action from other nations while doing little at home, despite the country's status as the world's largest greenhouse gas polluter through recent decades. And the United States was locked in an impasse with China, the world's other largest polluter as each country waited for commitments from the other before acting itself." ${ }^{19}$ Both Washington and Beijing changed their positions. Early in his second term President Obama made clear that he intended to put climate change at the heart of his legacy. China's President Xi Jinping, troubled by the dense fog that descended on his capital, vowed to act. Both presidents, meeting in Beijing, announced their intentions to go to Paris with ambitious plans to curb carbon emissions. The following month in Lima, Peru, negotiators wrote what would essentially become the Paris Agreement.

The biggest point of contention was over a push by the United States for an aggressive system to verify that countries were living up to their emission pledges. China and India argued that outside verification would be too intrusive. Small island states wanted a lower threshold than the 2 degrees Celsius the scientific community was pushing for. All developing countries wanted firm commitments to provide finance to deal with the consequences of global warming.

What could be expected from the Paris Agreement? The text calls for keeping the "increase in the global average temperature well below 2 degrees Celsius above pre-industrial levels and to pursue efforts to limit the temperature increase to 1.5 degrees." The lower threshold was a big win for small island states that had launched a vigorous campaign to get the lower threshold accepted. The Agreement called for "Global peaking of greenhouse emissions as soon as possible," followed by "rapid reduction thereafter." Emissions won't necessarily go to zero after 2050, but they will go low enough to be offset by natural growth of forests or development of carbon-capture technologies. Each country will deliver every five years a new pledge to further reduce emissions and "bend" the emissions curve downward. In the meantime, countries will step up "adaptations planning." Developed countries such as the United States, Germany, France and Britain will provide financial resources to developing ones to help them brace for the impact of climate change and also to transition to cleaner energy systems.

It is likely to encourage banks and investment funds to move their loan and stock portfolios from coal and oil to renewable energies such as wind and solar. There will be pressure on utilities themselves to cut their 
reliance on coal. Energy and technology companies will be pushed to make breakthroughs to make cheaper batteries that can store energy for use when it is needed. And automakers will have the incentive to develop electric and hydrogen cars. "It is very hard to go backward from something like this," said Nancy Pfund, managing partner of DBL Partners, a venture capital firm that focuses on social, environmental and economic development. "People are boarding this train, and it's time to hop on if you want to have a thriving, 21 st century economy."20

\section{Terrorism and Climate Change}

It may seem a bit of a stretch to suggest a link between climate change and the rise of various forms of extremist activities in the developing world. However, a little bit of reflection will show that such a link may well exist. That should worry policymakers in those parts of the world that are seeing both the rapid deterioration of the environment and the persistence of terrorism. In the world's hot and dry countries-which includes most of Africa, all of the Middle East and large parts of South Asia-there is growing unhappiness with the governments that are not working hard to protect the citizenry from heat and water shortages. Michael Krugelman of the Woodrow Wilson Center recently observed "that in Pakistan more people have died from the heat wave than from terrorism this year. We would emphasize that there shouldn't be a competition between 'terrorism' and 'climate stress' and that the resources spent on the former vastly outstrip the latter." It was not only heat that killed so many in Pakistan. Floods also took their toll on lives as well as property. By 2015, the country had had to deal with serious floods in five of the most recent seven years. Both heat and floods were predicted for South Asia by the World Bank study of climate change published in early 2015. These are extreme events that will increase in frequency as the concentration of carbon dioxide in the upper layers of the Earth's atmosphere continues to increase. As more climate related turbulence occurs, it will have economic consequences. These, unless addressed by public policy, will unsettle people and more of them may be tempted to move towards extremist ideologies. Although little research has been done on the subject, there appears to be a connection between persistent backwardness and attraction to extremist causes. As was pointed out in a report written in 2012 by the Burki Institute of Public Policy based in Lahore, while Punjab province had done well in promoting economic development, parts in the south were left behind. 
The backwardness of these parts was due to climatic factors. ${ }^{21}$ It is in these parts that extremist Islam has put down deep roots. Tashfeen Malik, one of the two terrorists that killed 14 people in an attack carried out in San Bernardino, California, had attended educational institutions in Multan, south Punjab's largest city.

That said, South Asians are remarkably resilient people, able to tolerate a great deal of mismanagement by those who govern. They do so largely because the political systems in the area provide an outlet. In the last couple of years the South Asians-first in Pakistan in 2013, and then in India, in 2014-threw out the incumbents and brought in those who seemed credible when they promised relief. But patience has its limits; this is especially the case when those who have used elections to force change don't have permanent political footing. A large number of them are footloose; they will move to other political spaces if they don't see the needed action being taken.

An uncomfortable citizenry is also a severely alienated one. It is alienation that leads people to find other ways to express themselves when political and economic systems are not working for them. This is not a new finding; it was pointed out decades ago by the Harvard University economist Albert Hirschman in his remarkably prescient book, Exit, Voice, and Loyalty. Hirschman suggested that in loyalty, voice and exit, alienated people had three possible options. ${ }^{22}$ Many people in the countries deeply affected by climate change are choosing the "exit" option. Some are just leaving and heading towards the places that offer better economic opportunities and better governance. This is what is driving hundreds of thousands of people to leave their homes in Africa and the Middle East and head towards Europe even when the chance of making it to their selected destinations is not all that great. Others are choosing different types of "exit." They are linking themselves with extremist groups that are promising change and hence an improvement in their situation.

It is interesting that in the summer of 2015, Iraq's prime minister, Haider al-Abadi, removed all three vice presidents in his government and the office of the deputy prime minister was abolished since the set-up over which he presided could supply electricity for only a few hours a day. His actions followed a wave of protests in which several thousand peopleworkers, artists, intellectuals-demonstrated on an exceptionally hot day. They walked through the center of Baghdad "chanting and carrying signs about the lack of electricity and blaming corruption for it," wrote Anne Barnard of the New York Times. "The protest was unusual in that it did 
not appear to have been called for by any major political party." ${ }^{23}$ This reaction by the people should not surprise Pakistan's citizens. They have now suffered for years from the absence of a regular supply of electricity to their homes and places of work. It is not surprising that Imran Khan and Tahir-ul-Qadri were able to galvanize hundreds of thousands of people to participate in their "dharnas" in the hot month of August 2014.

The columnist Thomas Friedman, writing about the world's hot spots, had an interesting take on how climate change will most likely affect the political future. "Here's my bet about the future of Sunni, Shiite, Arab, Turkish, Kurdish and Israeli relations," he wrote in a column published in August 2015. He could have added Indians and Pakistanis to the list of those who have unsettled differences. "If they don't end their longrunning conflicts, Mother Nature is going to destroy them all long before they destroy one another...Mother Nature is not sitting idle. She doesn't do politics-only physics, biology and chemistry. And if they add up the wrong way, she will take them all down."24

What should governments do to address the problems posed by climate change? To begin with they should work together to save "the commons." I am almost certain that the carefully prepared agendas for their high-level meetings by both India and Pakistan did not include climate change and its consequences for the region. That is unfortunate since this is the area where the governments should be working together to protect their countries and their people from the uncertainties associated with climate change.

\section{Conclusion: Could Technology Come to the Aid of Climate?}

According to experts, the plans submitted by major polluters in advance of the Paris summit will not to be enough to stave off the worst impacts of climate change. The group Climate Interactive showed in a report that the collective pledges would reduce the warming of the planet at the century's end to about 6.3 degrees Fahrenheit from an expected 8.1 degrees. That was a long way from meeting the target set in 2010 of limiting global warming to about $3.6 \mathrm{~F}$ degrees. ${ }^{25}$

However, there were reasons for optimism, largely because of a number of technological advances of recent years. As noted in Chap. 13 of 
the book, it was technological advances that proved the doomsayers who wrote the report Limits to Growth in the early 1970s wrong. The same was happening in the area of climate change. According to a report issued by the International Energy Agency, while in 2014 global economic output increased by $3 \%$, energy-related carbon dioxide emissions stayed flat, the first time that had happened in 40 years. Renewables accounted for nearly half of all new generation in 2014 and the energy intensity of the global economy dropped by twice as much over the past decade.

While technological change will help prevent the disaster that science predicts will happen if appropriate action is not taken, that action will depend to some extent on cooperation among the world's large economies. Li Shuo, Greenpeace's senor climate and energy policy adviser for East Asia, said that the climate accords reached by China and the United States bind the two countries together when the political horizon is hazy. "If there is a Republican president, you will have an interesting dynamic. Can he or she walk away from an agreement without worrying about the consequences if there is a commitment made by the presidents of the two countries? An aspect of this is the politics: binding these two countries together." 26

India's reluctance to adopt sterner measures to limit the use of coal for producing energy were justified by its senior policymakers in terms of the impact such an approach would have on the pace of growth and change in its economy. In an article contributed to the Financial Times on the eve of the Paris summit, Arvind Subramanian asserted that "for India-a country struggling to provide basic electricity to about 25 percent of the population, according to conservative estimates-this amounts to 'carbon imperialism.' And such imperialism on the part of advanced nations could spell disaster for India and other developing countries." His was an important voice in New Delhi's policymaking circles, as he was the Indian government's chief economic adviser. Technology could offer a solution, he thought. "Technologies that are already available, such as carbon capture and storage, have proved prohibitively expensive. To discover truly effective techniques, the world collectively needs to embark on a program akin to the Manhattan project that produced the first nuclear bomb. This would require investment from both public and private sectors, in advanced and developing nations, as well as a range of policy instruments." ${ }^{27}$ 


\section{Notes}

1. Peter Moore, "The Great Victorian weather wars," The New York Times, August 8, 2015, p. 23.

2. The Lancet, "Health and climate change: policy responses to protect public health," June 23, 2015.

3. Farhan Bokhari and Amy Kazmin, "Pakistan calls in army as hundreds die in heat wave," Financial Times, June 24, 2015, p. 2.

4. The World Bank, Now is the Time to Turn Down the Heat, Washington, DC, 2012.

5. Joby Warrick, "A warming globe brings disease threat," The Washington Post, November 28, 2015, pp. Al and A6.

6. Coral Davenport, "Obama's climate push is shaping contours of his coming legacy," The New York Times, November 29, 2015, p. 8.

7. Chris Mooney, "Environmental encyclical could transform discourse on ecological crisis," The Washington Post, September 26, 2015, p. A9.

8. Julie Hirschfeld Davis and Coral Davenport, "U.S. says China will announce cap-and-trade emissions plan," The New York Times, September 25, 2015, p. Al.

9. Jerry Patchell and Roger Hayter, "How big business can save the climate," Foreign Affairs, September/October, 2013, pp. 17-22.

10. Ibid.

11. World Energy Council report, 2013.

12. International Energy Agency (IEA), Medium-Term Coal Market Report, 2014.

13. Ibid. (1).

14. International Energy Agency, Power Generation from Coal: Measuring and Reporting Efficiency and Performance and CO2 Emissions, Paris, 2010.

15. Anjana Ahuja, "Cloned cows create a new beef over climate change," Financial Times, November 27, 2015, p. 9.

16. Richard L. Reversz and Jack Lienke, "Obama takes a crucial step on climate change," The New York Times, August 3, 2015, p. A21.

17. Mitch McConnell, "Obama's power plan power grab," The Washington Post, November 29, 2015, p. A25.

18. Ellen Barry and Coral Davenport, "India announces plan to lower rate of greenhouse gas emissions," The New York Times, October 2, 2015, p. A6.

19. Coral Davenport, "A climate deal, 6 fateful years in the making," The New York Times, December 14, 2015, pp. Al and A8.

20. Clifford Kraus and Keith Bradsher, "A signal to industry to go green in an era of carbon reduction," The New York Times, December 14, 2015, pp. Al and $\mathrm{B} 2$.

21. Burki Institute of Public Policy, The State of the Economy: The Punjab Story, Lahore, 2012. 
22. Albert O. Hirschman, Exit, Voice and Loyalty, Cambridge, MA: Harvard University Press, 1967.

23. Anne Barnardaug, " 120 degrees and no relief? ISIS takes back seat for Iraqis," The New York Times, August 1, 2015, p. All.

24. Thomas L. Freidman, "The world's hot spot," The New York Times, August 19, 2015, p. A23.

25. Climate Interactive, Tools for thriving future: Multisolving (v.) searching for systemic solutions while improving health, equity and well-being, August, Boston.

26. Steven Mufson, "Chinese president to target emissions," The Washington Post, September 25, 2015, p. Al3.

27. Arvind Subramanian, "India is right to resist the west's carbon imperialism," Financial Times, November 27, 2015, p. 9. 